\title{
Polska a nordycka larpologia stosowana 2010-2016
}

Michał Mochocki 


\section{Archiwum}

\section{Polska a nordycka larpologia stosowana 2010-2016}

Michał Mochocki

TEKSTY DRUGIE 2017, NR 3, S. 397-416

DOI: $10.18318 /$ td.2017.3.24

\section{Wprowadzenie}

Live action role play (larp), alias teatralne gry fabularne, z końcem 2014 roku zdobyły uwagę mainstreamowych mediów na całym świecie za sprawą polsko-duńskiego projektu „College of Wizardry”. Od tamtej pory Polska stała się ogniskiem larpowej turystyki, a głos polskich twórców na dobre zagościł w międzynarodowym dyskursie teoretyków i praktyków. Spora część tej dyskusji toczy się na żywo wokół prelekcji, warsztatów i rozmów na spotkaniach klubowych i konwentowych, po których rzadko pozostają archiwa. Część jest rozproszona w Internecie, na blogach (np. Akademii Rozwoju Argos ${ }^{1}$ lub Hardkon Larpers Retreat ${ }^{2}$ ), stronach fanowskich i grupach facebookowych (np. „LARP Poland”3). Niniejszy artykuł pomija tradycję ustną i pisarstwo internetowe,

1 Zob.http://www.argos.edu.pl/blog.

2 Zob.http://retreat.hardkon.pl/2016/blog-2.

3 Zob. https://www.facebook.com/groups/larp.poland.

\section{Michał}

Mochocki - dr,

adiunkt w Katedrze

Filologii Angielskiej,

organizator specjalizacji "Gamedec - badanie i projektowanie gier" na UKW w Bydgoszczy. Członek zarządu Polskiego Towarzystwa Badania Gier, członek Digital Games Research Association i International Games Developer Association. Zajmuje się niekomputerowymi grami fabularnymi, zwłaszcza w kontekście narracji, edukacji i aktywizacji dziedzictwa kulturowego. Kontakt: mochocki@ ukw.edu.pl 
analizując polską myśl „larpologiczną" przez pryzmat zredagowanych wydawnictw zwartych, które ukazały się w formie drukowanej jako książki lub czasopisma. Publikacje polskie z lat 2010-2016, popularne i naukowe, zostaną omówione w porównaniu $\mathrm{z}$ anglojęzycznymi z krajów nordyckich $\mathrm{z}$ tego samego okresu, gdyż to właśnie one:

jako pierwsze podjęły poważną refleksję teoretyczną nad swoim hobby - sztuką - profesją. Od 1997 na zmianę w Danii, Szwecji, Norwegii i Finlandii odbywa się doroczna konferencja Knutepunkt (norw. „miejsce spotkań"; z odmianami Knutpunkt/szw./, Knudepunkt/duń./ i Solmukohta /fin./), będąca platformą międzynarodowej wymiany wiedzy i doświadczeń. Początkowo odwiedzali ją uczestnicy prawie wyłącznie z krajów nordyckich, obecnie z całego świata, łącznie kilkaset osób. Od 2001 co roku (prócz 2002) towarzyszą jej publikacje w języku angielskim, dostępne w druku i w darmowych wersjach online. W konferencjach i publikacjach przenikają się ze sobą środowiska larpowych praktyków - twórców, organizatorów, artystów, pedagogów - i środowisko utytułowanych naukowo badaczy. Niejednokrotnie te same osoby zajmują się larpami z obu stron, będąc naukowcami z zawodu i czynnymi larperami z zamiłowania. W tym klimacie intelektualno-artystycznym zrodził się nurt, który nosi nazwę larpa nordyckiego. Termin spopularyzował się w 2010 wraz z publikacją książki Nordic Larp, ale przekonanie o swoistości „larpów w stylu knutepunktowym" już miało za sobą długą historię ${ }^{4}$

Polskie tradycje larpów w stylu nordyckim (alias: progresywnych), a więc traktowanych jako poważne przedsięwzięcia artystyczne, społeczne, edukacyjne itp., mają krótszy rodowód i znacznie skromniejszy dorobek publicystyczny. Podstawę porównania polskiej i nordyckiej „larpologii stosowanej”, czyli refleksji teoretycznej rozwijanej przez praktyków, stanowią publikacje z serii „KoLa - konferencja larpowa” z lat 2012-2016 oraz dwa tomy wydane przez Gdański Klub Fantastyki w 2012-2013. Wydawnictwom książkowym towarzyszą czasopisma: fanowskie „Inne Sfery”, „Larper” i „PAX!”, dział larpowy w komercyjnym piśmie „Magia i Miecz” oraz artykuły o larpach w naukowym magazynie „Homo Ludens”.

4 M. Mochocki Larp "College of Wizardry" jako produkt i platforma aktywizmu społecznego w druku. 


\section{Schyłek „rozbicia dzielnicowego" (do 2011)}

\subsection{Polska społeczność larpowa}

Ponadlokalną integrację środowisk larpowych rozrzuconych po Pomorzu, Małopolsce i Śląsku rozpoczął konkurs „Złota Brama” na konwencie Hardkon w roku $2008^{5}$, a przełom w stronę ogólnopolskiej integracji, umiędzynarodowienia, profesjonalizacji i teoretyzacji dokonał się w 2010-2011 roku. Po efemerycznej „Złotej Bramie”, po legendarnym wieczorku zapoznawczym wszystkich larpowych grup na Festiwalu Fantastyki Pyrkon w 2009 roku $^{6}$ nadszedł konkurs larpowy „Złote Maski”, organizowany na poznańskim Pyrkonie od 2010 roku nieprzerwanie do dzisiaj'. Lubelski klub Grimuar z Fundacją Szczęśliwe Dzieciństwo w 2010 roku zdobył finansowanie na programy larpowe w ramach międzynarodowej wymiany młodzieży ${ }^{8}$, również kontynuowane w dalszych latach. Członkowie wrocławskiego stowarzyszenia Wielosfer wzięli udział w czeskim konwencie larpowym „Odraz”, stykając się nie tylko ze sceną czeską, ale i z nordycką. Z „Odrazu” w 2010 roku przywieźli do Polski nowe formy larpowania, czyli freeform/jeepform', a także chęć rozwijania kontaktów zagranicznych i uporządkowanej refleksji teoretycznej ${ }^{10}$. Zaowocowało to w kolejnym roku licznym udziałem zagranicznych gości we wrocławskim festiwalu „Inne Sfery"11 i pierwszym wyjazdem Polaków (5 osób) na duński Knudepunkt ${ }^{12}$. Także w 2010-2011 roku upowszechniła się praktyka ponownego, nawet wielokrotnego rozgrywania

5 M. Augustynek Brama do przyszłości, w: Nasiona. Drzewa. Ogrody, red. P. Milewski, Stowarzyszenie Twórców Gier FUNREAL, Warszawa 2016, s. 115-117.

6 M. Wicher "Bóg, który się pomylił" rozmowa z Piotrem Milewskim, "Magazyn Konwentowy PAX” $2014 \mathrm{nr}$ 2, s. 40.

7 Złote maski, w: Festiwal Fantastyki Pyrkon 2016, http://pyrkon.pl/2016/zlote-maski (2.09.2016).

8 M. Słowikowski „Od Smoczych laj do Skrzydeł Wyobraźni” lubelskie projekty LARP-owe w ramach międzynarodowych wymian młodzieży, w: KoLa - Konferencja larpowa 2013, red. J. Tabisz, s. 16-19.

9 Freeform i jeepform to krótkie, niewielkie (nawet kilkuosobowe), formy dramowe z pogranicza teatralnych i narracyjnych gier fabularnych, często eksperymentujące z różnymi technikami ekspresji. Granica między jeepformem a freeformem jest nieostra; próbę rozgraniczenia podjął T. Wrigstad w The Nuts and Bolts of Jeepform, w: Playground Worlds. Creating and Evaluating Experiences of Role-Playing Games, ed. by M. Montola, J. Stenros, Ropecon, Helsinki 2008, s. 125-138, B. Zioło Wiele sfer gier, w: Nasiona. Drzewa. Ogrody, s. 85.

11 Tamże.

12 J. Tabisz Knudepunkt, czyli co się dzieje w LARPowym świecie, „Inne Sfery” 2011 nr 5, s. 4-5. 
sprawdzonych scenariuszy z kolejnymi grupami, co było odmianą po zwyczaju rozgrywania larpa tylko jeden raz ${ }^{13}$ (proces ten przebiegał równolegle w krajach nordyckich ${ }^{14}$ ).

\subsection{Publikacje nordyckie}

W 2010 roku ukazała się szczególna książka pod redakcją M. Montoli i J. Stenrosa, Nordic Larp, będąca podsumowaniem 15-letniej tradycji larpowej współpracy między krajami tego regionu. Redaktorzy to badacze z Uniwersytetu w Tampere, ich artykuły wprowadzające i podsumowujące zbiór dokonują naukowej analizy i teoretyzacji zjawiska. Większość ponad trzystustronicowego tomu stanowią nienaukowe, wspomnieniowe relacje z wybranych larpów, bogato ilustrowane materiałem zdjęciowym. Redaktorzy datują początki larpowego hobby na lata 80., a rozwój kontaktów ponadlokalnych na 90., z przełomową liczebnie i międzynarodowo (1000 graczy, szwedzko-norweska) grą „Trenne byar” z 1994 i pierwszym z dorocznych zjazdów Knutepunkt z 1997 roku 15 .

Publikacje knutepunktowe z lat 2010-2011 to Playing reality ${ }^{16}$ wydana na szwedzką edycję w 2010 roku i aż trzy tomy z duńskiej edycji Knudepunktu w roku 2011: akademicka Think larp ${ }^{17}$, dokumentalna Do larp ${ }^{18}$ i publicystyczna Talk larp ${ }^{19}$. W Playing reality dominuje podejście warsztatowe, czyli kwestie tworzenia, projektowania i organizowania, silnie obecny jest też wątek zastosowań w edukacji. Do larp idzie śladem Nordic Larp, jest albumem fotorelacji. Talk larp jest kolekcją krótkich, emocjonalnych felietonów - tak różnorodnych, że wymyka się próbom podsumowania. Z kolei Think larp przeszedł formalną procedurę recenzji double-blind, a autorów poproszono o refleksję opartą nie na wcześniejszych wydawnictwach

13 P. Milewski Dotąd i dalej, w: Nasiona. Drzewa. Ogrody, s. 108.

14 J. Trier-Knudsen Play it again, Sam, "Playground Magazine” 2012 nr 4.

15 J. Stenros, M. Montola The paradox of Nordic larp culture, w: Nordic Larp, ed. by J. Stenros, M. Montola, Fea Livia, Stokholm 2010, s. 15. E. Larsson Playing reality: articles on live action role-playing, Interacting Arts, Stokholm 2010.

T.D. Henriksen, Ch. Bierlich, K.F. Hansen, V. Kølle Think larp: academic writings from KP2011, Rollespilsakademiet, Copenhagen2011.

L. Andresen Do larp: documentary writings from KP2011, Rollespilsakademiet, Copenhagen 2011.

C. Raasted Talk larp: provocative writings from KP2011, Rollespilsakademiet, Copenhagen 2011. 
„larpologicznych", lecz na źródłach z formalnych dyscyplin naukowych ${ }^{20}$. Są to studia społeczno-kulturowe (subkulturowość, gender, larpy w Japonii) i medioznawcze (teatr, performans, film), a także psychologiczne i pedagogiczne'21.

W lutym 2011 roku światło dzienne ujrzał pierwszy numer anglojęzycznego kwartalnika nordyckiego „Playground Magazine” w wersji drukowanej i cyfrowej. Tematem wiodącym numeru \#1 jest efekt bleed (przenikania $)^{22}$ i związane z nim kwestie ryzyka i bezpieczeństwa psychologicznego w larpach. Artykuły dotyczą larpowego rozgrywania romansów i seksualności (w tym: sadomasochizmu), a także kontrowersyjnych wątków politycznych i społecznych. Są też teksty o zjawiskach pokrewnych larpom: komputerowych RPG, społeczności pick-up artists, performansach artystycznych. Na uwagę zasługuje wątek polski, czyli artykuł F.B. Østergaarda z wywiadami z Piotrem Milewskim i Jakubem Tabiszem i relacją z wizyty w Polsce, wówczas jeszcze "terra incognita" 23 dla nordyckich larperów. Numery 2 i 3 utrzymują tematykę: dominują kwestie seksualności i romansów, drugim wiodącym wątkiem są kwestie polityczno-społeczne, zwłaszcza możliwości symulowania mechanizmów opresji i nierówności społecznych.

„Playground” wspomina o publikacjach knutepunktowych i książce Nordic Larp, o inicjatywach artystycznych inspirowanych larpami, o konkursach na scenariusze larpowe. Widać, że publikacje nordyckie z lat 2010-2011 mają za sobą liczną, prężnie działającą społeczność, utrzymującą stałe kontakty, zainteresowaną wielokierunkowym rozwojem, wzajemną inspiracją i współpracą, a także sięganiem do kultur larpowych z innych krajów.

T.D. Henriksen, Ch. Bierlich, K.F. Hansen, V. Kølle Foreword, w: Think larp..., s. 8.

Podobny proces postępującego „unaukowienia” widać w analogicznym cykl publikacji amerykańskich, towarzyszącym konwentowi Wyrd Con, który od 2013 roku dzieli się na część publicystyczną i część naukową poddaną rygorowi recenzji peer review. Sporo autorów publikuje zarazem na łamach Wyrd Con i wydawnictw nordyckich.

Dotyczy przenikania odczuć i emocji między graczem jako osobą a bohaterem odgrywanym podczas larpa. Wyróżnia się bleed-in, gdy samopoczucie gracza-osoby przyniesione z realnego świata wywiera wpływ na odgrywanie bohatera w grze, oraz bleed-out, gdy emocje i przeżycia z gry będą towarzyszyć graczowi także po zakończeniu rozgrywki. Pisze o tym np. M. Montola The Positive Negative Experience in Extreme Role-Playing, w: DiGRA Nordic'10: Experiencing Games: Games, Play, and Players, 2010, s. 1-8.

F.B. Østergaard 9/11 and Back to the future, "Playground Magazine” 2011 No. 1, s. 39. 


\subsection{Publikacje polskie}

Fanowski magazyn „Kurier Kemocki” zaczą jako „kwartalnik grupy LARPowej Zardzewiały Topór" ${ }^{24}$ z numerami 1-3 z 2009 roku. Numer 4 z 2010 roku przyniósł zmianę nazwy na "Larper” i profilu z regionalnego (Pomorze) na ogólnopolski. Można rzec, że „Larper” był skromniejszym odpowiednikiem „Playground Magazine”. Tak jak „Playground”, sięga poza same larpy, do narracyjnych RPG i literatury fantastycznej. Inaczej niż „Playground”, sporo miejsca poświęca informacyjno-praktycznej stronie larpowego hobby, takiej jak newsy i relacje z larpów, praktyczne porady dotyczące wykonania kostiumów i rekwizytów, prezentacja zasad gry, gotowe scenariusze i pomysły. Także artykuły analityczno-teoretyczne rzadko wykraczają poza krótką (1-2 strony), popularną formę adresowaną do początkujących ${ }^{25}$. Zaawansowana refleksja nad sztuką i praktyką larpotwórstwa, która stanowi podstawę nordyckiego „Playground”, tu trafia się rzadko. Na 40 stron „Kuriera Kemockiego” nr 3/2009 przypadają dwa takie teksty: wywiad z doświadczonym twórcą ${ }^{26}$ i artykuł o larpach kameralnych ${ }^{27}$.

Wrocławskie „Inne Sfery” zaistniały w lutym 2010 roku jako czterostronicowa. czarno-biała gazetka stowarzyszenia Wielosfer. Numery 1-4 to informator klubowy z krótkimi newsami i zapowiedziami, gdzie oprócz larpów mieszczą się narracyjne RPG, gry planszowe i wideo oraz kącik literacki. Zmianę przynosi nr 5 z maja/czerwca 2011 roku, gdy liczba stron rośnie do 12, a oprócz newsów, shortów literackich, krzyżówek itp. pojawiają się artykuły i wywiady. Relacja z duńskiego Knutepunktu w nr 5 zachwyca się rozmachem i profesjonalizmem larpowej sceny nordyckiej, nie ukrywając żalu z powodu niższego poziomu w Polsce ${ }^{28}$. W nr 6 i 7 głównym tematem są krótkie formy dramowe zwane jeepformami, importowane m.in. z Norwegii, a promowane przez F.B. Østergaarda ${ }^{29}$. Na ostatniej stronie $\mathrm{nr} .7$ widnieje zapowiedź

24 M. Jesionowski Słowem wstępu, „Kurier Kemocki” 2009 nr 1, s. 3.

25 Np. M. Jesionowski Z wyobraźniq̨ o krok dalej - różnice między LARPem a RPG, "Kurier Kemocki” $2009 \mathrm{nr} 1$, s. 25-26. M. Jesionowski Wywiad z Piotrem „Fulko"Labenzem, „Kurier Kemocki” 2009 nr 3, s. 12-16. K. Chmielewski Pogwarka larpowa , "Kurier Kemocki” 2009 nr 3, s. 22-28.

28 J. Tabisz Knudepunkt czyli co się dzieje w LARPowym świecie , "Inne Sfery” 2011 nr 5, s. 4-5, https:// issuu.com/wielosfer/docs/innesfery-nr5 (11.11.2016).

29 J. Tabisz Uwaga! To nie będzie przyjemna gra! Wywiad z F.B. Østergaardem, "Inne Sfery” $2011 \mathrm{nr} 6$, s. 6-7, https://issuu.com/wielosfer/docs/innesfery-nr6 (11.11.2016). 
ogólnopolskiej konferencji larpowej, nadchodzącej w styczniu 2012. Konferencja okaże się kamieniem milowym na drodze do ponadlokalnej integracji środowiska (patrz niżej: 2.1).

Polskojęzyczna refleksja naukowa nad larpami w latach 2010-2011 prawie nie istniała. Znalazła się oprócz narracyjnych RPG w książce J. Szei z 2004 roku $^{30}$, później pojawiła się na łamach czasopisma „Homo Ludens” wydawanego przez Polskie Towarzystwo Badania Gier. Na lata 2010-2011 w „Homo Ludens” przypada jeden larpologiczny tekst J. Szei ${ }^{31}$, rok wcześniej - M. Mochockiego ${ }^{32}$. Oba dotyczą zastosowań larpów w edukacji historycznej i polonistycznej.

\section{Etap ogólnopolski (2012-2014)}

\subsection{Polska społeczność larpowa}

W styczniu 2012 roku we Wrocławiu odbyła się pierwsza polska „KoLa Konferencja Larpowa", której - wzorem nordyckich Knutepunktów - towarzyszyła popularnonaukowa publikacja wydana drukiem i w darmowej wersji elektronicznej. Pojawili się przedstawiciele różnych społeczności lokalnych, reprezentujący różne podejścia do larpów, co należy uznać za sukces w przełamywaniu partykularyzmów - inicjatywa wrocławska nie została zbojkotowana, lecz podjęta przez grupy z całej Polski. Na skalę krajową udało się zbudować podobną ponadlokalną społeczność, jak ta międzynarodowa w Skandynawii, łącząca regiony, dyscypliny i style. Na łamach publikacji, w blokach prelekcyjnych i w gronach organizatorów mieszają się gracze-pasjonaci, twórcy, organizatorzy, profesjonaliści zainteresowani wdrożeniami pozarozrywkowymi i komercyjnymi, również teoretycy i badacze (w tym naukowcy). Nierzadko te same osoby pełnią kilka funkcji i działają na kilku polach. Portal LarpBase ${ }^{33}$ zawiera nie tylko aktualności typu kalendarz larpowy, ale też archiwum publikacji konferencyjnych, artykuły o larpowej teorii,

30 J.Z. Szeja Gry fabularne - zjawisko kultury współczesnej, Rabid, Kraków 2004.

J.Z. Szeja Teatralne i narracyjne gry fabularne jako aktywizujace metody nauczania, „Homo Ludens" $2011 \mathrm{nr} 1$ (3), s. 215-235.

M. Mochocki Teatralne gry fabularne (LARP-y) w nauczaniu szkolnym, "Homo Ludens" $2009 \mathrm{nr} 1$, S. 177-189. 
a także zbiór gotowych scenariuszy, w tym format "print and play" nadający się do rozegrania bez udziału autora.

Na ten okres przypada wiele oficjalnych projektów realizowanych w partnerstwie $\mathrm{z}$ instytucjami, z dofinansowaniem publicznym lub biznesowym: edukacyjny „Projekt DEMOkracja” ${ }^{\text {"34, }}$, badawczy „Teatralne gry fabularne w nauczaniu szkolnym"35, powstają kolejne międzynarodowe projekty lubelskie ${ }^{36}$. Organizowane są szkolenia z projektowania larpów, m.in. „LubLarp”w Lublinie, „Letnie warsztaty dla twórców larpów” w Gdańsku, „Letnia szkoła larpowania” na konwencie Hardkon, „Liveform University” w Katowicach. Uniwersytet Kazimierza Wielkiego w Bydgoszczy w 2013 otworzył kierunek Humanistyka 2.0 ze specjalizacją „Gamedec: badanie i projektowanie gier”, w której programie znalazło się projektowanie larpów igier miejskich ${ }^{37}$.Także studia podyplomowe „Projektowanie gier edukacyjnych i szkoleniowych”, oferowane przez Akademię Marynarki Wojennej w Gdyni na rok 2017/18 $8^{38}$, obejmują tworzenie larpów.

Przełomowym wydarzeniem okazał się polsko-duński „College of Wizardry” z listopada 2014 roku. Skala i siła oddziaływania tego projektu wyznaczają koniec okresu ogólnopolskiego 2012-2014 i otwierają etap międzynarodowy, będzie więc omówiony w sekcji 3.1.

\subsection{Publikacje nordyckie}

Doroczna nordycka konferencja w 2012 odbyła się w Finlandii pod nazwą ,,Solmukohta", z publikacją już w tytule Nordic larp around the world podkreślającą ekspansję poza Skandynawię ${ }^{39}$. Jak na publikacje larpowe, zawiera spory blok tekstów o narracyjnych RPG. Kilka artykułów o larpotwórstwie porusza kwestie bezpieczeństwa, wcielania się w postać czy narzędzi projektowych. Przede

M. Mochocki, Ł. Wrona Projekt DEMOkracja: LARP w edukacji obywatelskiej, w: KoLa-Konferencja LARP-owa 2013, s. 20-26.

M. Mochocki Larping the past: research report on high-school edu-larp, w: Wyrd Con companion book 2014, ed. by S.L. Bowman, Wyrd Con, Los Angeles 2014, s. 132-149.

M. Słowikowski „Od Smoczych Jaj do SkrzydełWyobraźni”, w: KoLa - Konferencja LARP-owa 2013, S. 19 .

M. Mochocki Gamedec.UKW in IGDA Curriculum Framework, „Replay. The Polish Journal of Game Studies" 2016 nr 1.

Zob. http://www.gryszkoleniowe.amw.gdynia.pl

39 J. Pettersson States of play: Nordic larp around the world, Pohjoismaisen roolipelaamisen seura, Helsinki 2012. 
wszystkim jednak jest to zbiór artykułów wspomnieniowo-refleksyjnych, w których autorzy z wielu różnych krajów dzielą się przemyśleniami o graniu, prowadzeniu i tworzeniu larpów na przykładzie konkretnych realizacji. Po raz pierwszy w wydawnictwach Knutepunkt/Solmukohta pojawiają się teksty polskich autoró $w^{40}$. Poza cyklem konferencyjnym w 2012 wyszedł też zbiór o larpach edukacyjny $\mathrm{ch}^{41}$, zawierający relacje, refleksję pedagogiczno-warsztatową i prezentację przykładów z krajów nordyckich i ich współpracy z Białorusią.

W 2013 roku norweski Knudepunkt wydał publikację w czterech zeszytach o wspólnym motywie przekraczania granic. Tom o granicach fizycznych ${ }^{42}$ dotyczy udziału w larpach w innych krajach i kulturach i odwrotnie: przenoszenia larpów do innych krajów. Tom o granicach własnych przyzwyczajeñ ${ }^{43}$ skupia się na łączeniu larpa z innymi sferami: biznesem, edukacją, psychoterapią, sztuką, polityką. O granicach teoretycznych ${ }^{44}$ - zawiera krótkie teksty popularnonaukowe o różnych aspektach projektowania i analizy larpów, $\mathrm{z}$ naciskiem na aspekt narracyjny, światotwórczy i pisarski. Czwarty tom ${ }^{45}$ to album fotograficzny.

Na szwedzki Knutpunkt 2014 wydano dwa tomy. The Cutting Edge of Nordic Larp ${ }^{46}$, poświęcony najnowszym trendom i osiągnięciom, ma trzy główne tematy: a) zagadnienia projektowe, dotyczące głównie warstwy narracyjnej: pisania scenariuszy, postaci, fabuł; b) problematykę społeczno-polityczną i zaangażowanie larpów w działalność na rzecz zmiany społecznej; c) refleksję nad terminologią i definicjami. Dla akademickich badaczy szczególnie cenny jest tekst Harviainena, analizujący naukową wartość i użyteczność publikacji knutepunktowych oraz drogę, jaką przechodzą od obiegu popularnego do cytowań naukowych ${ }^{47}$.

40 play: Nordic larp around the world, ed. by J. Pettersson, s. 54-61; A. Mochocka The evaluation of elusiveness, w: States of play..., s. 140-146.

47

M.E. Andresen Playing the Learning Game, Fantasiforbundet, Oslo 2012.

\section{K. Svela, K.J. Meland Crossing physical borders, Fantasiforbundet, Oslo 2013.}

K. Svela, K.J. Meland Crossing habitual borders, Fantasiforbundet, Oslo 2013.

K. Svela, K.J. Meland Crossing theoretical borders, Fantasiforbundet, Oslo 2013.

K. Svela, K.J. Meland Exploring borders, Fantasiforbundet, Oslo 2013.

J. Back The cutting edge of nordic larp: Knutpunkt 2014, Knutpunkt, Malmö 2014.

J.T. Harviainen From hobbyist theory to academic canon, w: The cutting edge of nordic larp..., s. $183-188$. 
The Foundation Stone of Nordic Larp ${ }^{48}$ zawiera przedruki wybranych tekstów z lat minionych i stanowi propozycję swoistego kanonu dla nordyckiego dyskursu, z dodatkiem kilku nowych esejów będących próbą podsumowania i charakterystyki nordyckiej społeczności larpowej. Wybór tekstów odzwierciedla poglądy redaktorów na to, które tematy znajdują się w centrum zainteresowania: a) manifesty sztuki projektowania larpów, b) immersja w postać $\left.{ }^{49}, c\right)$ gry zlewające rzeczywistość z fikcją (pervasive $\left.)^{\mathbf{5 0}}, \mathrm{d}\right)$ efekt przenikania (bleed) emocji między grą a rzeczywistością, e) problematyka gender, f) problematyka polityczna, h) gry typu jeepform/freeform jako gatunek pokrewny larpom, j) problem bezpieczeństwa uczestników ${ }^{51}$.

Magazyn „Playground” w 2012 roku wypuścił numery 4-7. Nowy rok przyniósł zmianę tematyki. Miłość i seksualność zeszły na margines, zaś na pierwszy plan wysunęły się zagadnienia psychologiczne: efekt bleed, przemoc i tortury psychiczne w larpach więziennych, manipulowanie graczami, bezpieczeństwo czy efekt alibi ${ }^{52}$. Drugi kluczowy temat to sztuka tworzenia larpów: pisania, kreacji bohaterów, komunikacji z graczami, eksperymentowania

48 E. Saitta, M. Holm-Andersen, J. Back The foundation stone of nordic larp: Knutpunkt 2014, Knutpunkt, Eldsberga 2014.

Pojęcie immersji, czyli psychologicznej iluzji bycia bezpośrednio obecnym („zanurzonym”) w fikcyjnym świecie, jest jednym z kluczowych terminów badań nad grami. Dążenie do immersji w odgrywaną postać (immersjonizm) zostało już w 2003 roku zdefiniowane jako jeden z głównych celów uczestnictwa w larpach i do dziś pozostaje ważnym wątkiem larpologicznej refleksji. Por. P. Bockmann The Three Way Model. Revision of the Threefold Model for Scandinavian LARP, w: As Larp Grows Up, ed. by M. Gade, L. Thorup, M. Sander, Projektgruppen KPo3 2003, s. 12-18.

50 Gry typu pervasive w celowy sposób zamazują granicę między światem gry a codziennością, gdy informacje o grze oraz zadania dla graczy są umieszczone w codziennym środowisku gracza - na ulicach miast czy na portalach internetowych - a interakcja z nimi może odbywać się w dowolnym czasie, pomiędzy lub nawet podczas innych codziennych czynności. W języku angielskim dostępna jest publikacja książkowa: M. Montola, J. Stenros, A. Waern Pervasive Games: Theory \& Design, CRC Press 2009. Po polsku na temat gier rzeczywistości alternatywnej pisze m.in. A. Mochocka Alternate Reality Games - gry rzeczywistości alternatywnej - zjawisko graniczne, "Homo Ludens” 2011 nr 1, s. 117-138.

E. Saitta, M. Holm-Andersen, J. Back Introduction to the essays, w: The foundation stone of nordic larp...,

Termin „alibi” dotyczy tu poczucia psychologicznego bezpieczeństwa i społecznej akceptacji przy wcielaniu się w kontrowersyjne role i odgrywaniu scen przekraczających strefę komfortu (przemoc, intymność, zbrodnia, fanatyzm religijny itp.). O technikach i sposobach stwarzania larpowego poczucia alibi pisze m.in. L.N. Andresen Alibi for Religious Ecstasy, „Playground Magazine" 2013 No. 5, s. 28-32. 
z formą. Pojawia się autor polski, pisząc o narracyjnych RPG ${ }^{53}$. „Playground” stale śledzi też larpowe i okołolarpowe wydarzenia, przedsięwzięcia i zwyczaje w krajach nordyckich i za granicą - artystyczne, naukowe, edukacyjne, polityczne, wydawnicze i biznesowe. Jednak po publikacji nr. 7 „Playground” zamilkł, a w grudniu 2013 roku ogłosił definitywny koniec działalności ${ }^{54}$.

\subsection{Publikacje polskie}

Polski „Larper” zakończył działalność na numerze siódmym, tak samo jak „Playground Magazine"55. Po zmianie nazwy w 2010 roku, na nr 5 przyszło czekać do roku 2012 (datowany na marzec-maj), zapowiadający utrzymanie formy kwartalnika. Z trzech dalszych numerów planowanych na 2012 wyszedł jeden, nr 6 (październik 2012-styczeń 2013). Numer 5 rozpoczyna się anonimową minirecenzją książki Nordic Larp, w której czytamy: „Skandynawowie larpują o wiele dłużej niż my, dlatego mają większe możliwości i doświadczenie. Powinniśmy się na nich wzorować, ale nie kopiować i osiąnnąć własny styl larpów"56. Zgodnie z tą myślą numery 5 i 6 są znacznie poważniejsze niż 1-4 i znacznie bardziej nordyckie. W dosłownym tego słowa znaczeniu, gdyż zawierają tłumaczenia z „Playground Magazine” i omówienia paru larpów z Nordic Larp. Głównym wątkiem staje się importowana ze Skandynawii krótka forma dramowa zwana jeepformem. Znajduje się jednak wciąż miejsce na larpy polskie. Numer 7 (datowany już nie kwartalnie, lecz rocznie) z 2013 roku znów wprowadza sekcję dla początkujących, a głównym tematem czyni ogólnopolski konkurs larpowy „Złote maski”.

Wrocławskie „Inne Sfery” w 2012-2013 roku wydały numery 8-11 i również zamknęły działalność. Wciąż jest to skromny fanzin liczący od 12 do 27 stron, do tego w znacznej mierze wypełniony newsami, recenzjami filmów, gier i literatury i krótkimi tekstami literackimi, więc na uczestnictwo w zaawansowanym dyskursie nie zostaje wiele miejsca. Jednak i tam regularnie

53 J. Kopeć Master of puppets, „Playground Magazine” 2012 No. 4, s. 26-29.

C. Raasted It's dead. Really. This time for real, blog Playground Roleplaying Magazine, 10.12.2013, https://playgroundroleplayingmagazine.wordpress.com/2013/12/10/its-dead-really-this-time-for-real (1.11.2016).

Archiwum numerów 1-7 dostępne przez link w: M. Jesionowski Kim i czym jest LARPer? Darmowy magazyn LARP i RPG, blog "Ja Ty Gry", 11.08.2015, http://jatygry.blogspot.com/2015/08/ kim-i-czym-jest-larper.html (10.11.2016). 
pojawiają się artykuły poruszające kwestie aktualne w Skandynawii: psychologia wczuwania się w postać, odgrywanie zachowań seksualnych, psychiczne i fizyczne bezpieczeństwo, zaawansowane techniki tworzenia i prowadzenia larpów, analizy popularnonaukowe (np. opisanie dynamiki larpa przez teorię chaosu ${ }^{57}$ ). „Inne Sfery” są też na bieżąco z działalnością społeczności larpowej, publikują zapowiedzi i relacje z konferencji, konkursów, szkoleń i innych projektów.

W 2014 roku pojawił się i zniknął „Magazyn Konwentowy PAX!”, określający się jako „Magazyn wypełniony po brzegi praktycznymi poradnikami, kontrowersyjnymi felietonami, intrygującymi pomysłami, kreatywnymi scenariuszami, zapowiedziami, opisami, recenzjami oraz zajadłą krytyką (tudzież pochwałą) konwentów" ${ }^{\text {58. }}$ W istocie, był pełen zapowiedzi, relacji i komentarzy do gier i życia społeczności, porad dotyczących charakteryzacji, kostiumów i rekwizytów, także reklam i kolorowych fotografii. Jednak i tam, zwłaszcza w numerze 2/2014, znalazło się miejsce na głębszą refleksję nad wizją artystyczną, wyzwaniami organizacyjnymi, reprezentacją seksualności i przemocy, a także przemocy seksualnej i innych form traumy. Na łamach „PAX!” Dembiński diagnozuje stan rozwoju polskiego dyskursu larpowego w porównaniu z nordyckim i bałkańskim i twierdzi: „Dogoniliśmy osnute legendami kraje nordyckie w naszej sztuce tworzenia larpów i zrozumieliśmy, jak wykorzystać otwierające się przed nami perspektywy" ${ }^{59}$. Być może „PAX!" dorównałby „Playground Magazine”, gdyby na drugim numerze nie dokonał żywota.

Drugą nowością na rynku wydawniczym było wskrzeszenie w 2014 roku „Magii i Miecza”, pierwszego polskiego czasopisma o grach RPG, które w latach 9o. kładło podwaliny pod rozwój gier fabularnych w naszym kraju, a upadło w 2003 roku. Prym wiodą tam gry narracyjne (tabletop RPG), lecz stałe miejsce zyskał także dział larpowy pod redakcją Piotra Milewskiego. Mimo że nr 1 pojawił się pod koniec 2014 roku, zostanie omówiony wraz z numerami z 2015 roku, w sekcji 3.3.

Gdański Klub Fantastyki w 2012 i 2013 roku wydał tomy Larp: myśli i szki$c e^{60} \mathrm{i}$ Larp: twarze i maski - pokłosie letnich warsztatów dla twórców. Zgodnie

57 K. Bartczak Nieliniowa dynamika larpów (cz. 1), "Inne Sfery” 2012 nr 9, s. 16-19.

58 Od redakcji, "Magazyn Konwentowy PAX!” 2014 nr 1, s. 3.

59 D. Dembiński Polishing the edge of Nordic larp, "Magazyn Konwentowy PAX!” 2014 nr 2, s. 26.

60 K. Chmielewski Larp: twarze i maski, Gdański Klub Fantastyki, Gdańsk 2013. 
z profilem warsztatów tomy dotyczą przede wszystkim zagadnień projektowych: pisania scenariuszy, tworzenia postaci, doboru mechaniki (zasad), analizy już istniejących systemów gry. W pierwszym tomie ukazało się kilka scenariuszy gier stworzonych na warsztatach lub po nich. W drugim tylko jeden, za to uwagę zwraca pokaźna objętość larpowej teorii opatrzonej bibliografią. Autorzy sięgają po zaawansowane modele projektowe, rozważają psychologiczne aspekty udziału w larpach, analizują i prognozują trendy. Jak pół żartem, pół serio pisze redaktor, „zaczęła zawiązywać się w Polsce społeczność praktyków-badaczy, szukających innowacyjnych rozwiązań w grach, czytających, co tylko z zagranicznej literatury larpowej wpadnie im w ręce. Pozostali rodzimi twórcy, żeby konkurować z tą bandą szaleńców w walce o rząd dusz i skrzynie otulinowych mieczy, muszą także sięgać do literatury" ${ }^{\prime \prime 1}$. W tomie z 2013 roku w bibliografii pojawiają się teksty polskie, nordyckie i amerykańskie. Niestety, wydawnictwa GKF-u ukazały się w skromnym drukowanym nakładzie i do dziś nie mają wersji elektronicznej. Trudność dostępu znacząco ograniczyła ich wpływ na rozwój debaty.

Najważniejsze polskie wydawnictwa larpowe z tego okresu to publikacje z konferencji „KoLa”, kolejno z lat 2012 $22^{62}, 2013^{63}$ i $2014^{64}$. Znaczną część stanowią relacje i refleksje nad zrealizowanymi grami, reprezentującymi różne style - duże terenowe gry fantasy, artystyczne formy teatralne, dbające o scenografię larpy zamkowe, sprzężone z pasją historyczną gry sarmackie. Pośród zagadnień organizacyjnych i projektowych częściej niż w tomach nordyckich pojawia się mechanika (zasady). Wśród rozważań ogólnych przewijają się te same tematy, co w publikacjach nordyckich: seksualność, potencjał edukacyjny, bezpieczeństwo psychiczne, techniki i sposoby projektowania, organizowania i prowadzenia gier, problemy definicyjne, związki larpów z innymi mediami. Jednym z podobieństw jest też obecność autorów zagranicznych, Yaraslaua Kota z Białorusi i Ivana Žalaca z Chorwacji. Zmierzając ku umiędzynarodowieniu polskiego dorobku, wydawnictwa „KoLa” 2012-2014 wydano również w tłumaczeniu angielskim.

61 K. Chmielewski Wstęp, w: Larp: twarze imaski, s. 6.

62 J. Tabisz KoLa-Konferencja Larpowa, Wielosfer, Wrocław 2012.

63 J. Tabisz KoLa - Konferencja Larpowa 2013, Wielosfer, Wrocław 2013.

64 M. Słowikowski, D.K. Trojanowska KoLa - konferencja larpowa 2014. Myślą, słowem i uczynkiem, Stowarzyszenie Twórców Gier FUNREAL, Gdynia 2014. 
W naukowym magazynie „Homo Ludens” w 2012 roku pojawił się raport z badań nad larpami w nauczaniu historii ${ }^{65}$, a w 2014 - artykuł o dramie podczas lekcji języka obcego ${ }^{66}$. Projekt badawczy nad historycznymi edu-larpami, prowadzony w latach 2012-2013 przez Polskie Towarzystwo Badania Gier i wydawnictwo Nowa Era, doczekał się także publikacji anglojęzycznych w europejskim „International Journal of Role Playing”67 i amerykańskim Wyrd Con Companion ${ }^{68}$.

\section{Etap międzynarodowy (2015+)}

\subsection{Polska społeczność larpowa}

"College of Wizardry" ${ }^{69}$, zrealizowany na zamku Czocha (gm. Leśna, dolnośląskie) przez duńską Rollespilsakademiet i polski Liveform, zdobył globalny rozgłos ${ }^{70}$ i wyznaczył początek ery międzynarodowej. Jednym z jej aspektów jest powstanie turystyki larpowej w polskich zamkach, której uczestnicy rekrutują się także spoza środowiska larpowego71. Drugim - nagły wzrost zainteresowania Polską w nordyckiej (i globalnej) społeczności larpowej i zarazem wzrost aktywności Polaków na scenie międzynarodowej. Konferencja Larpowa 2015, organizowana w Warszawie niespełna dwa miesiące (2-4.01.2015) po „College of Wizardry”, zyskała liczny odsetek zagranicznych gości i prelegentów. Liczba polskich uczestników Knudepunktu (12-15.02.2015) z kilkorga w latach poprzednich wzrosła do piętnaściorga.

65 M. Mochocki Teatralne gry fabularne (LARP-y) na lekcjach historii - raport z badań, "Homo Ludens" 2012 nr 4, s. 149-172.

66 A. Marko Drama na lekcjach języka obcego - o potencjale metody, "Homo Ludens" 2014 nr 6, s. 87-100.

67 M. Mochocki Edu-larp as revision of subject-matter knowledge, "International Journal of Role Playing" $2013 \mathrm{nr}$ 4, s. 55-75.

68 M. Mochocki Larping the past: research report on high-school edu-larp, w: Wyrd Con companion book2014, s. 132-149.

69 Zob. www.cowlarp.com.

70 Linki do relacji medialnych z całego świata zebrał: J. Axner College of Wizardry 2014 round-up, w: Nordiclarp.org, 11.12.2014, https://nordiclarp.org/2014/12/og/college-of-wizardry-2014-round-up (1.10.2016).

D. Dembiński Świat larpowej turystyki, w: Nasiona. Drzewa. Ogrody. KoLa-konferencja larpowa 2016, red. P. Milewski. 
W tym polski głos po raz pierwszy pojawił się w prestiżowej serii Nordic Larp Talks, nadawanej na żywo przez Internet i wciąż dostępnej jako nagranie archiwalne $^{72}$.

Można rzec, że wraz z przełomem 2014/2015 poziom polskiego dyskursu i doświadczenia larpowego dorównał nordyckiemu. Ruch jednokierunkowy, w którym Polska sięgała po wzory i inspiracje za granicę, ustąpił dwukierunkowemu, w którym polskie doświadczenia i osiągnięcia inspirują twórców zagranicznych. Larpowe projekty w muzeach, szkołach i domach kultury, a także larpowe festiwale przestały być rzadkością, a niewykluczone, że wkrótce staną się normą. Powstał też nowy cykl „Larp Design Conference" ${ }^{\text {"73, }}$ branżowa konferencja dla profesjonalnych twórców, organizowana przez ten sam duńsko-polski zespół, który stworzył „College of Wizardry”. Anglojęzyczna, międzynarodowa i dość kosztowna (150 euro) stanowi kolejny dowód na integrację polskiej sceny z zagraniczną. Na fali globalnej popularności larpów w turystyce i rekreacji powstała też konferencja "College of Extraordinary Experiences"74, przeznaczona dla wysokiej klasy specjalistów z wielu branż medialnych i rozrywkowych, dla których wspólnym mianownikiem jest experience design - projektowanie przeżyć użytkownika.

\subsection{Publikacje nordyckie}

Na duński Knudepunkt w 2015 wydano zbiór fotorelacji z larpów roku minionego ${ }^{75}$ oraz jeden zbiór artykułów ${ }^{76}$ (w obu jest mowa o "College of Wizardry"). W artykułach zwraca uwagę rozwój debaty nad psychologiczną immersją gracza w postać - pojawia się koncepcja świadomego sterowania (steering) postacią i jej immersją77. Drugim ważnym tematem nadal są zaawansowane

72 A. Lubańska Wizardry 101, w: Nordic Larp Talks, 12.02.2015, https://nordiclarptalks.org/wizardry-101-agata-swistak-lubanska (01.09.2016).

Zob. http://www.larpdesignconference.com.

Zob. https://www.extraordinary.college.

C.B. Nielsen, C. Raasted The Nordic Larp Yearbook 2014, Rollespilsakademiet, Copenhagen 2015.

C.B. Nielsen, C. Raasted, M. Balzer The Knudepunkt 2015 companion book, Rollespilsakademiet, Copenhagen2015.

M. Pohjola Steering For Immersion in Five Nordic larps: A new understanding of eläytyminen, w: The Knudepunkt 2015 companion book, ed. by C.B. Nielsen, C. Raasted, M. Balzer; M. Montola, J. Stenros, E. Saitta The Art of Steering: Bringing the Player and the Character Back Together, w: The Knudepunkt 2015 companion book 
modele i praktyki projektowe. Trzecim - kwestia sporządzania, selekcji i rozpowszechniania dokumentacji larpowej, m.in. zdjęć i nagrań wideo.

Fińska Solmukohta z 2016 roku także przyniosła dwie książki - jedną poświęcono tekstom polityczno-społecznym ${ }^{\mathbf{7 8}}$, a drugą pozostałym kwestiom teoretycznym i praktycznym ${ }^{79}$. Larp politics analizuje larpy jako narzędzie symulacji mechanizmów władzy i opresji, a także wykorzystywania tego potencjału dla edukacji, protestu, publicystyki i zmiany społecznej; swoją sekcję ma także problematyka gender. Larp realia przygląda się różnym aspektom projektowania i analizowania larpów, w tym strukturze narracji i oddziaływaniu psychologicznemu. Dwa teksty są pióra polskich autorów: Bartczak proponuje system realistycznego odgrywania przemocy fizycznej ${ }^{\mathbf{8 0}}$, Zioło kreśli inspiracje dla larpów zaczerpnięte z gry wideo Skyrim ${ }^{\mathbf{8 1}}$.

W 2015 roku w Moskwie ukazała się książka Nordic-Russian Larp Dialog, zredagowana przez naukowo utytułowanych badaczy ${ }^{\mathbf{8 2}}$ - pomost między anglojęzycznym światem larpów Europy Zachodniej a obszarem rosyjskojęzycznym. W części nordyckiej mowa o immersji psychologicznej, larpowej dramaturgii, realizmie scenografii; w rosyjskiej - o strukturze narracji, projektowaniu dylematów, symbolicznej reprezentacji, o syberyjskich larpach egzystencjalnych. Publikacja ta stanowi ważny krok na drodze trwającej już od kilku lat współpracy nordyckich larperów z krajami dawnego Związku Radzieckiego.

\subsection{Publikacje polskie}

Magazyn „Magia i Miecz” wydał, jak dotąd, sześć numerów: od nr 1 we wrześniu 2014 do nr 6 z października 2016 roku. Dział larpowy zajmuje około 20 stron. Przeważa krótka forma popularyzatorska, nastawiona na czytelnika początkującego: artykuły wprowadzające do larpowania lub w przystępny sposób przybliżające warsztatowe aspekty tworzenia larpów: mechanikę,

78 K. Kangas, M. Loponen, J. Särkijärvi Larp Politics - Systems, Theory, and Gender in Action, Ropecon ry, Helsinki 2016.

J. Särkijärvi, M. Loponen, K. Kangas Larp Realia - Analysis, Design, and Discussions of Nordic Larp, Ropecon ry, Helsinki 2016.

80 K. Bartczak Introducing physical violence to larps, w: Larp Realia, ed. by J. Särkijärvi, M. Loponen, K. Kangas.

81 B. Zioło Create your own larp adventure, w: Larp Realia, ed. by J. Särkijärvi, M. Loponen, K. Kangas.

82 A. Fedoseev, J.T. Harviainen, O. Vorobyeva Nordic-Russian Larp Dialog, Comcon, Moskwa 2015. 
psychologię gracza, seksualność. Głębsza refleksja pojawia się przede wszystkim w wywiadach z doświadczonymi twórcami. „Magia i Miecz” boryka się z opóźnieniami, nie spełniając założeń kwartalnika, jednak dotąd (koniec 2016) nie złożyła broni.

Kluczowe dla polskiej myśli larpologicznej pozostają tomy towarzyszące konferencji „KoLa”. „Inside/Outside” z $2015^{83}$ kontynuuje refleksję nad warsztatem larpotwórczym: projektowanie przeżyć graczy, zasady gry, logistyka organizacyjna, inspiracje innymi mediami, pisanie scenariuszy. Sporo miejsca poświęcono larpom w edukacji, zwłaszcza historycznej. Z punktu widzenia relacji między polską a nordycką „sceną”, na uwagę zasługuje „Manifest larpingu post-progresywnego", który potwierdza tezę o zakończeniu okresu naśladownictwa i poczucia niższości wobec zagranicy. Sygnatariusze wyrażają uznanie dla dorobku progresywnej szkoły nordyckiej, lecz twierdzą, że:

Formuła ta, niegdyś przełomowa dla jakości larpów, dziś zdaje się wyczerpywać. Skierowawszy larpy na nowe tory, uwolniła je od roli wyłącznie rozrywkowej, lecz obarczyła je przy tym bagażem założeń, zasad i metodyk, które dziś wydają się zbędnym balastem [...] odmawiamy uznania jakiejkolwiek formy twórczej jako jedynej słusznej [...] Sprzeciwiamy się uznaniu jakichkolwiek elementów metodologii za obowiązkowe. [...] Nie oczekujemy od twórcy larpów spełnienia żadnych predefiniowanych warunków, wymagamy w zamian świadomości stosowanych środków i powziętego celu. ${ }^{84}$

Rok 2016 stał się dla „KoLi” rokiem podsumowań i zestawień. Ułożony chronologicznie tom stanowi rzut oka na 25-letnią historię larpów w Polsce, począwszy od pierwszych eksperymentów z lat $80 .{ }^{85}$ po otwarcie nowego nurtu turystyki przez „College of Wizardry" ${ }^{\text {"66 }}$. W tymże roku ukazała się Księga larpów polskich, pierwszy polski odpowiednik nordyckich książek

83 M. Słowikowski, G. Woźniczko Inside/Outside. KoLa - konferencja larpowa 2015, Stowarzyszenie Twórców Gier FUNREAL, Katowice 2015.

84 K. Bartczak i in. Manifest larpingu post-progresywnego, w: Inside/Outside, s. 12.

85 D. Wiktorowicz Prehistoria larpów w Polsce, w: Nasiona. Drzewa. Ogrody.

86 P. Milewski Nasiona. Drzewa. Ogrody. KoLa - konferencja larpowa 2016, Stowarzyszenie Twórców Gier FUNREAL, Warszawa 2016. 
dokumentalnych ${ }^{87}$ - galerie fotografii z najciekawszych bądź najważniejszych projektów z najnowszej i dawnej historii polskich larpów, opatrzonych krótkimi opisami po polsku i angielsku. Publikacja ukazała się drukiem w twardej oprawie oraz w darmowej wersji elektronicznej i stanowi ważne osiągnięcie w popularyzacji polskiego dorobku w międzynarodowej społeczności larpowej.

\section{Podsumowanie}

W roku 2010, gdy lokalne środowiska larpowe zaczęły wyraźnie dążyć ku ogólnopolskiej współpracy i profesjonalizacji, kraje nordyckie miały już za sobą około dwudziestoletni dorobek w zakresie takich działań na poziomie międzynarodowym. $Z$ dążeniem do doskonalenia warsztatu i umiejętności praktycznych (jako twórcy, organizatorzy, projektanci) szedł w parze rozwój refleksji teoretycznej, niekiedy naukowej, którą polscy larperzy czerpali przede wszystkim z krajów nordyckich, ale też z innych krajów Europy, USA i Rosji. Analiza drukowanych publikacji z okresu od 2010 do 2016 ukazuje trzy fazy rozwoju polskiego środowiska twórców, praktyków i teoretyków teatralnych gier fabularnych.

2010-2011: Dążenie do zawiązania ogólnopolskiej współpracy i wymiany doświadczeń między lokalnymi grupami larpowymi, połączone z pewnym kompleksem niższości wobec sceny nordyckiej i z próbami jej naśladownictwa;

2012-2014: Rosnąca profesjonalizacja hobby, intensywna wymiana doświadczeń wewnątrz kraju, rozwój kontaktów zagranicznych i szeroka adaptacja wzorów nordyckich. Towarzyszą tym procesom liczne wydawnictwa czasopisma i tomy konferencyjne - których tematyka jest zbieżna z nordycką.

2015+: Otwarta sławnym duńsko-polskim „College of Wizardry" z końca 2014 roku integracja polskiej społeczności z zagraniczną, łącznie z wymianą doświadczeń w drugim kierunku: polscy twórcy publikują, popularyzują i znajdują naśladowców za granicą.

Ani polska, ani nordycka społeczność nie utrzymała regularnego czasopisma, lecz obie wypracowały trwały cykl dorocznych konferencji i tomów konferencyjnych, wydawanych drukiem i online. Interesująco przedstawia się ich status akademicki: zasadniczo, są to wydawnictwa popularne, a zawarte

87 M. Wicher Księga larpów polskich / The Book of Polish Larp. Rollespilsakademiet, Copenhagen 2016. 
w nich analizy i teorie pisane są przez praktyków, zazwyczaj studentów i absolwentów, na podstawie wiedzy ze studiów i własnych lektur. Regularnie publikują tam też zawodowi, naukowo utytułowani badacze, którzy często wywodzą się ze społeczności graczy i twórców, będąc „aka-fanami” w rozumieniu H. Jenkinsa ${ }^{88}$. Piszą zwykle stylem popularnonaukowym, ale trafiają się teksty gęste od akademickiej teorii, obficie opatrzone przypisami i bibliografią. Wyjątkowe miejsce zajmuje książka Think larp z 2011 roku, wydana w popularnej serii konferencji Knutepunkt/Solmuhohta, która przeszła formalną procedurę recenzji naukowej double-blind.

Harviainen, omawiając status i funkcjonowanie tekstów „knutepunktowych" w obiegu naukowym, podkreśla ciągły wzrost poziomu i aktywny udział naukowców w tworzeniu dyskursu, który nazywa półnaukowym (semi-academic) ${ }^{89}$. A prawdziwej wartości tych publikacji dla świata nauki upatruje nie tyle w dorobku teoretycznym, co empirycznym: „Są empiryczną dokumentacją badań terenowych, empirią projektowania, empirią badań nad graczami, a także hipotezami opartymi o tę empirię. Nie są to systematyczne dane empiryczne, lecz to nie przekreśla ich przydatności"90. Nordyckie i anglojęzyczne studia groznawcze (game studies), w tym nad odgrywaniem ról (role-playing studies) obficie cytują z popularnych wydawnictw larpologicznych, a jak przypomina Harviainen, głos artystów o uznanym dorobku (np. $\mathrm{w}$ dziedzinie teatru) nieraz jest brany pod uwagę w refleksji badawczej i mimo że nie ma charakteru naukowego, zyskuje podobną pozycję dzięki liczbie cytowań ${ }^{91}$. Czy polskie wydawnictwa larpowe czeka podobna kariera w świecie nauki? Zapewne nie, gdyż pojawiły się stosunkowo późno, gdy larpologiczny „kanon” zdążył się już uformować. Polscy badacze larpów nie dość, że są nieliczni, to nieraz publikują w języku angielskim, na podstawie źródeł o zasięgu międzynarodowym, więc największe szanse mają tu angielskie tłumaczenia tomów z konferencji „KoLa”. Czy po polską larpologię popularnonaukową sięgną inni naukowcy, np. badacze dramy, performansu, fandomów, kultury

H. Jenkins About me, w: "Confessions of an Aca-Fan", http://henryjenkins.org/aboutmehtml (02.05.2016).

J.T. Harviainen From hobbyist theory to academic canon, w: The cutting edge of nordic larp, s. 186.

90

"They are documented empirics of field research, empirics of design, empirics of player studies and - also - hypotheses based on those empirics. They are by no means systematic empirics, but that does not mean they are not valuable".

91 Tamże, s. 185. 
uczestnictwa, narracji transmedialnych, psychologii immersji, innowacji dydaktycznych? Być może niniejszy tekst się do tego przyczyni.

\section{Abstract}

\section{Michał Mochocki}

KAZIMIERZ WIELKI UNIVERSITY (BYDGOSZCZ)

Applied Larpology in Poland and the Nordic Countries, 2010-2016

Mochocki examines Polish 'larpology' through an analysis of print publications - edited books and magazines that appeared between 2010 and 2016. These are compared to similar English-language publications from the Nordic Countries. The analysis suggests three stages:

2010-2011: attempts to foster nationwide cooperation between local larp groups, combined with a certain inferiority complex towards the Nordic scene and attempts to emulate it;

2012-2014: The hobby becomes increasingly professionalized; an intense exchange of experiences takes place across the country, foreign contacts are developed and Nordic models are adapted. This is accompanied through a number of publications - magazines and conference proceedings - whose themes overlap with Nordic publications.

2015+: The Danish-Polish 'College of Wizardry' opens the door for a the Polish community's deep integration with foreign ones, including a bilateral exchange of experiences. Now the Polish larp community publishes and popularizes its work abroad, finding international followers.

\section{Keywords}

Larp, game studies, role-playing, theatrical role-playing 